\title{
Carbon storage in soils of Southeastern Nigeria under different management practices
}

\author{
Martin AN Anikwe
}

\begin{abstract}
Background: Changes in agricultural practices-notably changes in crop varieties, application of fertilizer and manure, rotation and tillage practices-influence how much and at what rate carbon is stored in, or released from, soils. Quantification of the impacts of land use on carbon stocks in sub-Saharan Africa is challenging because of the spatial heterogeneity of soil, climate, management conditions, and due to the lack of data on soil carbon pools of most common agroecosystems. This paper provides data on soil carbon stocks that were collected at 10 sites in southeastern Nigeria to characterize the impact of soil management practices.

Results: The highest carbon stocks, $7906-9510 \mathrm{gC} \mathrm{m}^{-2}$, were found at the sites representing natural forest, artificial forest and artificial grassland ecosystems. Continuously cropped and conventionally tilled soils had about $70 \%$ lower carbon stock (1978-2822 $\mathrm{gC} \mathrm{m}^{-2}$ ). Thus, the soil carbon stock in a 45-year old Gmelina forest was $8987 \mathrm{gC} \mathrm{m}$ 2, whereas the parts of this forest, that were cleared and continuously cultivated for 15 years, had $75 \%$ lower carbon stock (1978 $\mathrm{gC} \mathrm{m}^{-2}$ ). The carbon stock of continuously cropped and conventionally tilled soils was also $25 \%$ lower than the carbon stock of the soil cultivated by use of conservation tillage.

Conclusion: Introducing conservation tillage practices may reduce the loss of soil carbon stocks associated with land conversion. However, the positive effect of conservation tillage is not comparable to the negative effect of land conversion, and may not result in significant accumulation of carbon in southeastern Nigeria soils.
\end{abstract}

\section{Background}

Soil organic carbon is a large and active pool, containing roughly twice as much carbon as the atmosphere and 2.5 times as much as the biota. Carbon sequestration is the facilitated redistribution of carbon from the air to other pools. This would reduce the rate of atmospheric $\mathrm{CO}_{2}$ increase, thereby mitigating global warming $[1,2]$.

The amount of carbon sequestered at a site reflects the long-term balance between influx and efflux of carbon. Recent concerns with rising atmospheric levels of $\mathrm{CO}_{2}$ have stimulated interest in $\mathrm{C}$ flow in terrestrial ecosystems and the latter's potential for increased soil carbon sequestration [3]. Carbon enters the soil as roots, litter, harvest residues, and animal manure. It is stored primarily as soil organic matter (SOM). The density (w/v) of carbon is highest near the surface, but SOM decomposes rapidly, releasing $\mathrm{CO}_{2}$ to the

Correspondence: anikwema@yahoo.co.uk Department of Agronomy and Ecological Management, Faculty of Agriculture and Natural Resources Management, Enugu State University of Science and Technology, P.M.B. 01660 Enugu, Nigeria atmosphere. Some carbon becomes stabilized, especially in the lower part of the profile. However, in many areas, agricultural and other land use activities have upset the natural balance in the soil carbon cycle, contributing to an alarming increase in carbon release $[4,5]$. Since the current rise in atmospheric $\mathrm{CO}_{2}$ is thought to be mitigated in part by carbon sequestration in agricultural soils [4], interest has increased in the possible impacts of various agricultural management practices on soil organic matter dynamics [6].

Agricultural and other land use practices have a significant influence on how much carbon can be sequestered and how long it can be stored in the soil before it is returned to the atmosphere. The best strategies focus on the protection of soil organic carbon against further depletion and erosion, or the replenishment of depleted carbon stocks through certain management techniques [2]. In either case, the keys to successful soil carbon sequestration are increased plant growth and productivity, increased net primary production and decreased decomposition [2]. Similarly, conversion of marginal 
arable land to forestry or grassland can rapidly increase soil carbon sequestration. For example, analysis of longterm crop experiments indicated that increasing crop rotation complexity increased SOC sequestration by 20 $\mathrm{gC} \mathrm{m}^{-2} \mathrm{yr}^{-1}$, on average [7]. In long-term experiments in Canada, SOC sequestration rates were 50 to $75 \mathrm{gC} \mathrm{m}^{-2}$ $\mathrm{yr}^{-1}$ in well-fertilized soils with optimal cropping [8]. By contrast, long-term experiments in the northern Great Plains (US) have shown that fertilizer $\mathrm{N}$ increased crop residue returns to the soil, but generally did not increase SOC sequestration [9]. Ogunwale and Raji [8] found that after 45 years of cow dung and NPK treatments to a soil in Samaru Northern Nigeria, soil organic carbon content in the unamended soil was $1.81 \mathrm{tC} \mathrm{ha}^{-1}$ or 10 $\mathrm{gC} \mathrm{m}^{-2}$ between 1977 and 1995. In the same period of 45 years, the use of continuous NPK application resulted in only slight increase in SOC (3\%) over the unamended soil while manure with NPK gave $115 \%$ more SOC. They found that the rate of SOC sequestration during fallow period in their experiment was approximately $400 \%$ more than the rates under continuous cultivation.

Timing and intensity of tillage also must be taken into account in the design of best management practices for maximizing SOC sequestration [10-12].

In most of Africa including Nigeria, research on quantification of carbon stored in the soil is proceeding slowly. Thus, data on soil $\mathrm{C}$ pools are lacking for most common agro-ecosystems. It is important to note that data collected from tropical environments are used in estimating total world carbon sequestration potential because differences in edaphoclimatic conditions and soil management practices influence the storage of carbon in the soil. For example, with the exception of histosols that have 13-27\% soil organic matter (by weight) [13], average soil organic matter contents of soils in sub-Saharan Africa range (between) $0.5-3.0 \%$ whereas temperate Europe and America soils record up to 10$13 \%$ soil organic matter. Quantifying changes in soil C is a difficult task. Annual changes per year are small compared to $\mathrm{C}$ already present, and its spatial variability can be very large [14]. Thus, reliable estimates of C change depend on sampling randomly at test sites over many years or by sampling at specific locations, repeatedly over time [15].

African countries are unlikely to engage in soil carbon sequestration unless there are clear local economic and societal benefits. Therefore, it is essential to estimate all potential costs and benefits related to the various management options. Large-scale adoptions of ecologically sound land use practices are likely to be the most cost effective and environmentally friendly option to increase soil carbon sequestration in Africa [2]. In addition, a correct measurement and verification of carbon sequestration potential of soils in sub-Saharan Africa would enable the zone to participate in the Clean Development Mechanism (CDM), proposed in Article 12 of the Kyoto Protocol to the United Nations Framework Convention on Climate Change. This will allow developing countries to sell or trade project-based carbon credits, such as Carbon Emission Reduction (CER) credits, to or with industrial countries, if adopted. CER credits could provide an incentive for participation in climate change mitigation and cover the costs that African participants will encounter when engaging in carbon sequestration [2].

The objective of this work, therefore, is to assess quantitatively, the effect of different soil management practices on soil organic carbon sequestration.

\section{Results}

\section{Soil properties of the study sites}

Results of the study (Table 1) indicate low, medium and high coefficients of variability among soil properties at the different sites studied. There was a low coefficient of variability (6-9\%) in bulk density and soil $\mathrm{pH}$ in $\mathrm{CaCl}_{2}$ at the different soil depths studied, whereas silt + clay content and percent sand content showed medium variability (20-30\%). The highest SOC content (3.07\%) was found in site No. 6 (natural undisturbed forest) (Table 2), whereas lowest SOC was observed in site No. 10 (conventionally-tilled, continuously-cropped plot (CT-CC) (0.81\%) S0C and site No. 2 (CT-CC Plot) (0.83\%) (SOC). Lowest SOC levels were found in sites 2 , 5 and 10 (CT-CC plots) with SOC range of between $0.59-0.83 \%$. Ratings by Landon [16] in the study area show $1.16 \%$ SOC or lower to be low, whereas SOC values $\geq 1.74 \%$ and above are regarded as high. Sites 2 and 10 as shown in Table 1 , were conventionally-tilled and continuously cropped soils.

The highest total $\mathrm{N}$ content of the soils ranged from $0.29-1.95 \mathrm{Mg} \mathrm{kg}^{-1}$. These were found at sites 8,7 and 6 . These plots were either artificially planted forests or natural undisturbed forests (Table 3), whereas sites 2, 10 and 5 had low $\mathrm{N}$ content, and correspond to plots that were conventionally- and continuously-tilled. Results show slight differences in $\mathrm{pH}$ values for the different soils studied. However, sites 5 and 10, which were continuously- and conventionally-tilled plots, were among the plots with the lowest soil $\mathrm{pH}$.

\section{Quantity of carbon stock in the soils under different soil management regimes}

Results of the study show that there were differences in total quantity of carbon sequestered in the different land utilization types in the study area (Table 2). These differences were confirmed by the high coefficient of variation (55\%) between the SOC content of the different land use types. 
Table 2 Total quantity of soil organic carbon $\left(\mathrm{gC} \mathrm{m}^{-2}\right)$ stored at the $\mathbf{0 - 3 0} \mathrm{cm}$ soil layer of the study soils

\begin{tabular}{lllll}
\hline $\begin{array}{l}\text { Site } \\
\text { Number }\end{array}$ & $\begin{array}{l}\mathbf{0 - 5} \text { (Mean }+ \\
\text { SEM) }\end{array}$ & $\begin{array}{l}\text { Soil Depth } \\
\mathbf{5 - 1 5} \\
\text { (Mean }+ \\
\text { SEM) }\end{array}$ & $\begin{array}{l}\mathbf{1 5 - 3 0} \\
\text { (Mean }+ \\
\text { SEM) }\end{array}$ & Total \\
\hline 1. & $918.8 \pm 12$ & $1793.4 \pm 2$ & $1788 \pm 44$ & 4500.2 \\
2. & $630.8 \pm 28$ & $1240 \pm 15$ & $951.6 \pm 23$ & 2822.4 \\
3. & $1501.5 \pm 34$ & $2811.6 \pm 33$ & $2712.6 \pm 20$ & 7025.7 \\
4. & $1897.2 \pm 26$ & $3699 \pm 18$ & $3391.6 \pm 26$ & 8987.8 \\
5. & $387.5 \pm 18$ & $812.2 \pm 15$ & $778.8 \pm 31$ & 1978.5 \\
6. & $2010.9 \pm 15$ & $3828 \pm 30$ & $3672 \pm 15$ & 9510.9 \\
7. & $1426.8 \pm 24$ & $3075 \pm 42$ & $3404.8 \pm 56$ & 7906.6 \\
8. & $1308 \pm 33$ & $2551.5 \pm 46$ & $2523.2 \pm 13$ & 6382.7 \\
9. & $763.2 \pm 12$ & $1450 \pm 21$ & $1391.2 \pm 17$ & 3604.4 \\
10. & $603.5 \pm 30$ & $1087.2 \pm 34$ & $1078 \pm 20$ & 2768.7 \\
\hline CV (\%) & 65.3 & 54.5 & 56.3 & $55.1 \%$ \\
\hline
\end{tabular}

The highest quantities of SOC were stored in sites 6, 4 and 7 with $9510.9,8987.8$ and $7906.6 \mathrm{gC} \mathrm{m}^{-2}$ in the 0-30 $\mathrm{cm}$ soil layers, respectively (Table 2 ). These sites correspond to natural undisturbed forest, artificial forest and artificial grassland, respectively. Only slight differences in carbon stock (absolute difference between maximum and minimum value: $1604 \mathrm{gC} \mathrm{m}^{-2}$ ) were found between the three land uses with the highest carbon stocks and that may be either because of differences in plant biodiversity, differences in bulk densities of the soils studied or slight differences in local climatic regimes.

The lowest carbon stocks in the 10 study locations were found in sites 5, 2 and 10. These have SOC stocks of $1978.5,2822.4$ and $2768.7 \mathrm{gC} \mathrm{m}^{-2}$ in their $0-30 \mathrm{~cm}$ soil layer, respectively. These plots correspond to conventionally-tilled and continuously-cropped plots. When compared to the sites with the highest carbon stocks (forest and grassland land use types), results show $71 \%$ depletion in carbon stock in the conventionally-tilled, and continuously-cropped plots. More specifically, the quantity of carbon sequestered in site 4 (planted forest) was $8989.8 \mathrm{gC} \mathrm{m}^{-2}$. This was higher than that stored in an adjacent cultivated site (site 5) by as much as $78 \%$ (Table 2). Assuming that this forest reached a steady-state condition (balanced input and output of SOC), it took 15 years of continuous cultivation and conventional tillage to lose $78 \%$ of its carbon stock built over the years.

Results show that at site 8 (Abakaliki, Artificial Gmelina arborea forest with alleys cultivated with food crops), the quantity of carbon sequestered was 6382.7 $\mathrm{gC} \mathrm{m}^{-2}$ at $0-30 \mathrm{~cm}$ soil depth. This quantity was higher than the carbon stock found in site 1 (another Abakaliki plot, conventionally-tilled and continuously-cropped by $30 \%)$. In contrast, only a slight difference $(5 \%)$ in 
Table 3 Location, classification and land use history of the 10 sites used for the study

\begin{tabular}{|c|c|c|c|}
\hline $\begin{array}{l}\text { Site } \\
\text { Number }\end{array}$ & $\begin{array}{l}\text { Location/Annual } \\
\text { rainfall }\end{array}$ & $\begin{array}{l}\text { Soil } \\
\text { Classification }\end{array}$ & Land use history \\
\hline 1 & $\begin{array}{l}\text { Abakaliki I } 6^{\circ} \\
19^{\prime} \mathrm{N}, 8^{\circ} 06^{\prime} \mathrm{E} 2069 \mathrm{~mm}\end{array}$ & $\begin{array}{l}\text { Aquept } \\
\text { Flood Plain }\end{array}$ & $\begin{array}{l}\text { Conventionally-tilled with traditional hoes, planted with } \\
\text { Cassava }\{\text { Manihot esculenta\}/vegetables (Amaranth }\{\text { Amaranthus hybridus\}, Okra \{Albemoschus } \\
\text { esculentus\},Waterleaf }\{\text { Talinum triangulare\} }) / \text { maize }\{\text { Zea mays\} intercrop with 2-year fallow period } \\
\text { in } 10 \text { years, no fertilization, crop residues not removed. }\end{array}$ \\
\hline 2 & $\begin{array}{l}\text { Enugu I } 6^{\circ} 27^{\prime} \mathrm{N}, 7^{\circ} 29^{\prime} \mathrm{E} \\
1792 \mathrm{~mm}\end{array}$ & $\begin{array}{l}\text { Typic Paleustult } \\
\text { Midslope }\end{array}$ & $\begin{array}{l}\text { Conventionally-tilled with traditional hoes, continuously-cropped with maize/cassava/yam } \\
\text { \{Dioscorea rotundata\} intercrop for ten years. NPK 15:15:15 fertilizers used at low doses (30-50 kg } \\
\mathrm{ha}^{-1} \text { ), crop residues left in the field. }\end{array}$ \\
\hline 3 & $\begin{array}{l}\text { PortHarcourt } \\
4^{\circ} 46^{\prime} \mathrm{N}, 7^{\circ} 01 \mathrm{E} \\
2450 \mathrm{~mm}\end{array}$ & $\begin{array}{l}\text { Typic Paleustult } \\
\text { Floodplain }\end{array}$ & $\begin{array}{l}\text { Conventionally-tilled, unmulched, cropped to maize and cassava for } 12 \text { consecutive years, } \\
\text { fertilized with low dose ( } 30-50 \mathrm{~kg} \mathrm{ha}^{-1} \text { ) of NPK 15:15:15 fertilizer, crop residues left in the field. }\end{array}$ \\
\hline 4 & $\begin{array}{l}\text { Enugu II } \\
06^{\circ} 27^{\prime} \mathrm{N}, 7^{\circ} 32^{\prime} \mathrm{E} \\
1792 \mathrm{~mm}\end{array}$ & $\begin{array}{l}\text { Typic paleustult } \\
\text { Midslope }\end{array}$ & $\begin{array}{l}\text { Artificial forest established by Forestry Department in 1962. Planted with Gmelina arborea and } \\
\text { Tectona grandis (Teak). }\end{array}$ \\
\hline 5 & $\begin{array}{l}\text { Enugu III } \\
06^{\circ} 27^{\prime} \mathrm{N}, 7^{\circ} 32^{\prime} \mathrm{E} \\
1792 \mathrm{~mm}\end{array}$ & $\begin{array}{l}\text { Typic paleustult } \\
\text { Midslope }\end{array}$ & $\begin{array}{l}\text { Adjacent land near the artificial forest cropped-continuously for } 15 \text { years with cassava, yam, } \\
\text { pulses and vegetables in a mixed culture. No fertilization and crop residues not removed. }\end{array}$ \\
\hline 6 & $\begin{array}{l}\text { Ihe,Awgu I } \\
06^{\circ} 30^{\prime} \mathrm{N}, 7^{\circ} 15^{\prime} \mathrm{E} \\
1752 \mathrm{~mm}\end{array}$ & $\begin{array}{l}\text { Typic paleudult } \\
\text { Toeslope }\end{array}$ & $\begin{array}{l}\text { Natural undisturbed forest (sacred land). Had existed for more than } 80 \text { years. People are } \\
\text { forbidden entry. Hunting of animals/games and cutting of trees/fetching of firewood not } \\
\text { allowed. }\end{array}$ \\
\hline 7 & $\begin{array}{l}\text { Enugu IV } \\
06^{\circ} 27^{\prime} \mathrm{N}, 7^{\circ} 25^{\prime} \mathrm{E} \\
1750 \mathrm{~mm}\end{array}$ & $\begin{array}{l}\text { Typic Paleudult } \\
\text { Midslope }\end{array}$ & $\begin{array}{l}\text { Artificial grassland (golf course) established in } 1934 \text {. } \\
\text { Mainly made up of Paspalum notatum, Axonopus compressus } \\
\text { and Cyperus rotundus. Regularly cut and fertilized with N:P:K 15:15:15 fertilizer. }\end{array}$ \\
\hline 8 & $\begin{array}{l}\text { Abakaliki II } \\
6^{\circ} 04^{\prime} \mathrm{N}, 8^{\circ} 65^{\prime} \mathrm{E} \\
2069 \mathrm{~mm}\end{array}$ & $\begin{array}{l}\text { Typic } \\
\text { Haplaudult } \\
\text { Crest }\end{array}$ & $\begin{array}{l}\text { Artificial Gmelina arborea forest established } 30 \text { years ago. } \\
\text { The alleys between the trees are currently cropped with different food crops(cocoyam, yam, } \\
\text { cowpea, maize) by urban farmers. Municipal wastes used for fertilization, conventionally-tilled. }\end{array}$ \\
\hline 9 & $\begin{array}{l}\text { Nsukka, I } \\
6^{\circ} 52^{\prime} \mathrm{N}, 7^{\circ} 24^{\prime} \mathrm{E} \\
1700 \mathrm{~mm}\end{array}$ & $\begin{array}{l}\text { Typic Paleustult } \\
\text { Footslope }\end{array}$ & $\begin{array}{l}\text { University Research plot, fallowed for two years, conservation tillage, planted with maize and } \\
\text { groundnut, fertilization with NPK 15:15:15 at } 90 \mathrm{~kg} \mathrm{ha}^{-1} \text { and poultry droppings at } 10 \mathrm{Mg} \mathrm{ha}^{-1} \text { for } \\
\text { three years. }\end{array}$ \\
\hline 10 & $\begin{array}{l}\text { Ihe,Awgu II } \\
06^{\circ} 30^{\prime} \mathrm{N}, 7^{\circ} 05^{\prime} \mathrm{E} \\
1752 \mathrm{~mm}\end{array}$ & $\begin{array}{l}\text { Typic Paleudult } \\
\text { Toeslope }\end{array}$ & $\begin{array}{l}\text { Farmers plot, conventionally-tilled, planted with cassava/maize/vegetables (fluted pumpkins, } \\
\text { cabbage, cowpea, Amaranth) with 2-year fallow interval, NPK 15:15:15 fertilizers used at low } \\
\text { doses (30-50 kg ha }{ }^{-1} \text { ), crop residues left in the field, farm managed as stated for } 12 \text { years. }\end{array}$ \\
\hline
\end{tabular}

total carbon stock was found between site 6 (natural undisturbed forest and site 4 (artificial forest).

\section{Discussion}

High coefficients of variability in organic carbon and total $\mathrm{N}$ content were observed for soil organic carbon (SOC; 53-55\%) and between 178-184\% for total N. High variability in SOC and total $\mathrm{N}$ content may indicate soil properties that are mostly impacted on the short to medium term by changes in soil management practices. Although measured values of bulk density even among the same soil vary considerably because densification of surface soil is caused by many factors viz. trafficking by humans and animals, wetting and drying cycles in soils, raindrop impact energy, etc. [17], the low coefficient of variation observed among the different soils used for the study especially in cultivated plots, may come from the fact that samples were collected at the end of the harvesting season when soil re-compaction after tillage may have occurred. However, bulk density values are most useful in carbon sequestration studies for the calculation of total quantities of carbon sequestered at a particular time and soil depth. Krull et al. [18] stated that almost all organic carbon in soil is located within pores between mineral particles either as discrete particles or as molecules adsorbed onto the surfaces of these mineral particles. Soil architecture can influence biological stability of organic materials through its effects on water and oxygen availability, entrapment and isolation from decomposers, and through the dynamics of soil aggregation.

The highest SOC content was found in natural undisturbed forest, whereas lowest S0C was observed in conventionally-tilled, continuously-cropped plots. Previous studies by [17] and [19] showed that tillage adversely affects carbon storage in the soil. However, although sites 3 and 9 were continuously-tilled plots, their SOC contents were considerably high $(2.3$ and $1.06 \%$ in the 0-5 cm soil layer, respectively) when compared to sites either under grassland or forests probably because site 3 is a natural floodplain (see Table 3 ) whereby it seemed that enrichment of SOC occurred during yearly flooding. For site 9 in particular, the plot was managed under conservation tillage with annual addition of $20 \mathrm{t} \mathrm{ha}^{-1}$ of 
poultry droppings for 3 years. These may have drastically increased SOC of sites 3 and 9. Differences in SOC content of site 4 (Artificial Gmelina arborea forest) and site 5 (adjacent CT-CC plot) show that land clearing and continuous cultivation drastically reduce SOC. Bationo et al. [20] in studying soil organic carbon dynamics, functions and management in West African agro-ecosystems reported rapid decline of SOC levels with continuous cultivation. For the sandy soils, they found that average annual losses may be as high as $4.7 \%$ whereas with sandy loam soils, losses were lower, with an average of $2 \%$. They postulated that total system carbon in different vegetation and land use types indicated that forests, woodland and parkland had the highest total and aboveground carbon content demonstrating potential for carbon sequestration. For example, total system carbon in the Senegal River valley was 115 ton $\mathrm{ha}^{-1}$ in the forest zone and only 18 ton $\mathrm{ha}^{-1}$ when the land was under cultivation. Cultivated systems have reduced carbon contents due to reduced tree cover and increased mineralization due to surface disturbance.

Generally, it seemed that SOC reduced with sampling depth at all sites used for the study. The continuouslyand conventionally-tilled plots were among the plots with the lowest soil $\mathrm{pH}$ probably because of mining of exchangeable cations by growing crops in continuouslytilled plots. Generally, soil $\mathrm{pH}$ increased with soil depth in most of the sites studied. Mineralogy, surface charge characteristics, and precipitation of amorphous Fe and $\mathrm{Al}$ oxides on clay mineral surfaces define the capacity of clay minerals to adsorb and potentially protect SOC [21].

Results of this study also indicate that although site 3 was conventionally-tilled and cultivated for 12 consecutive years, it stored up to $7025 \mathrm{gC} \mathrm{m}^{-2}$. This may be because crop residues were always left in the field after harvesting but more importantly because it is a floodplain. It is likely that soil materials including $\mathrm{C}$ may have been transported from other places and deposited there. However, for site 9 (fallowed for 2 years, conservation till + fertilizer + poultry droppings and planted with maize) carbon stock was $3604 \mathrm{gC} \mathrm{m}^{-2}$, which was higher than the $\mathrm{C}$ values for plots 10 and 2 (conventionally-tilled, continuously-cropped plots) by up to $23 \%$.

The quantity of carbon stored in the natural forest was greater than that of the artificial forest by $5 \%$ probably because of greater diversity of plant species found at the natural forests and to a lesser extent because the natural forests are older than the artificial forests. However, [21] and [22] have shown that both natural and artificial forest attain steady-state conditions after several years and thereafter only slight changes in SOC content are possible unless extraneous factors like climatic shifts occur.
These results show that conventional tillage reduces soil carbon stocks when compared to other management practices. However, the amounts and rates of carbon sequestration vary according to natural factors such as climate (temperature and rainfall) and soil physical characteristics (soil texture, clay mineralogy and soil depth) as well as agricultural management practices.

\section{Conclusion}

The results of this study have shown that different management systems impact on the ability of the soil to sequester carbon. In tropical hot climates as those found in the study area, natural undisturbed forests, artificial forests and grasslands store between 7906-9510 $\mathrm{gC} \mathrm{m}^{-2}$ within the first $0-30 \mathrm{~cm}$ soil layer, whereas cultivated and continuously-cropped lands sequester about 1978-3604 $\mathrm{gC} \mathrm{m}^{-2}$ depending on the management system adopted. In other words, the large-scale conversion of forests to croplands in the southeastern Nigeria may lead to $50-75 \%$ loss in the regional soil carbon stock.

\section{Methods}

\section{Site description}

Soil samples were collected from 10 sites in different parts of southeastern Nigeria. Differences in management practices and edaphoclimatic properties guided choice of the different sites. Southeastern Nigeria stretches from $04^{\circ} 15^{\prime} \mathrm{N}$ to $07^{\circ} 00^{\prime} \mathrm{N}$ and between $05^{\circ} 34^{\prime} \mathrm{E}$ and $09^{\circ} 24^{\prime} \mathrm{E}$, has a total area of approximately 78,612 $\mathrm{km}^{2}$ [23]. Mean annual temperature ranges between $27-$ $32^{\circ} \mathrm{C}$. The soils of the zone have isohyperthermic temperature regime and receive average annual rainfalls of between $1600 \mathrm{~mm}-4338 \mathrm{~mm}$ [23].

\section{Observations and data collection}

The soil samples used for the experiment were collected from 10 sites representing:

(a) Forests:

(i) An Artificial forest established by Forestry Department in 1962.

(ii) A Natural undisturbed forest (sacred land) that is more than 80 years old.

(iii) An Artificial Gmelina arborea forest established 30 years ago the Forestry Department.

(b) Grassland:

(i) Artificial grassland (golf course) established in 1934.

(c) Arable land

(i) Plot conventionally-tilled with traditional hoes, planted with cassava/vegetables/maize intercrop with 2year fallow period in 10 years.

(ii) Plot conventionally-tilled with traditional hoes, continuously-cropped with maize/cassava/yam intercrop for ten years. 
(iii) Plot conventionally-tilled, unmulched, cropped to maize and cassava for 12 consecutive years.

(iv) Land adjacent to the artificial forest cropped continuously for 15 years with cassava, yam, pulses and vegetables in a mixed culture.

(v) University Research plot, fallowed for two years and managed under conservation tillage for three years.

(vi) Farmers plot, conventionally-tilled, planted with cassava/maize/vegetables and used for 12 years.

The details of site number, location, soil classification and land use history are presented in Table 3.

An initial (reconnaissance) survey was carried out in the 10 sites selected for the study to establish sampling points. Nine representative sampling points were chosen in each selected site using the free survey approach (observation points that are representative of the site are chosen by the surveyors based on personal judgment and experience) [24]. Three sampling depths (0-5, 5.115 and $15.1-30 \mathrm{~cm}$ ) were used for the study. At each depth, nine undisturbed core samples and nine auger samples were collected for laboratory analysis.

The samples were collected at the end of the harvesting season in October when bulk density of tilled cropped fields had reverted to their pre-tillage conditions (because soil bulk density measurements are used for calculating carbon stocks) [17]. In cultivated plots, samples were collected randomly inside the rows. Auger samples were collected using a hand-pushed auger (Push Probe, $23 \mathrm{~mm}$ diameter). Core samples were collected using open-faced coring tube (area, $19.5 \mathrm{~cm}^{3}$ and height, $5 \mathrm{~cm}$ from Eijkelkamp Agrisearch Equipment) at the three selected depths. Roots, twigs, and leaves were manually removed from auger samples and the samples air-dried at ambient temperature for 72 hours and subsequently sieved (using $2 \mathrm{~mm}$ sieves). Core samples were analyzed and mean results from each depth used whereas auger samples collected at a specific depth, were mixed and composite sub-samples (from each depth) used for further analyses.

The carbon stock in each agro ecological system was calculated with the formula $=\mathrm{C}(\%) / 100 \times$ soil bulk density $\times$ area $(1 \mathrm{ha}) \times$ soil depth

\section{Laboratory methods}

Samples were analyzed in the Research Laboratory of the Department of Soil Science, University of Nigeria, Nsukka, for bulk density, gravimetric water content, organic carbon content, total nitrogen, soil $\mathrm{pH}$ and particle size distribution. Bulk density was analyzed by core method [25]. Organic carbon was determined by the Walkley-Black procedure [26]. Total nitrogen was by the Macro-Kjeldahl method [27], whereas soil pH on a saturated sample was determined in soil electrolyte $(0.01 \mathrm{M}$ $\mathrm{CaCl}_{2}$ ) suspension using a glass electrode $\mathrm{pH}$ meter
(Digital pH meter, Accumet Model AR15, Fisher Scientific). Particle size distribution was determined using the pipette method of Gee and Orr [28].

\section{Competing interests}

The authors declare that they have no competing interests.

Received: 16 June 2010 Accepted: 26 September 2010

Published: 26 September 2010

\section{References}

1. Soil Science Society of America: Carbon sequestration in soils: Position of the Soil Science Society of America. SSSA Ad Hoc Committee S893 Report, USA 2001.

2. Tieszen LL: Carbon Sequestration in semi-arid and sub-humid Africa. U.S. Geological Survey, EROS Data Center, Sioux Falls, South Dakota 2000 [http:// edcintl.cr.usgs.gov/ip].

3. Huggins DR, Buyanvsky GA, Wagner GH, Brown JR, Darmody RG, Peck TR, Lesoing GW, Vanotti MB, Bundy LG: Soil organic $C$ in the tall grass prairiederived region of the Corn Belt: effect of long-term management. Soil and Tillage Research 1998, 47:227-242.

4. Schlesinger WH: Carbon sequestration in soils. Nature 1999, 284:2095-2096.

5. Schlesinger $\mathrm{WH}$, Lichter J: Limited carbon storage in soils and litter of experimental forest plots under increased atmospheric $\mathrm{CO}_{2}$. Nature 2001, 411:466-469.

6. Dick WA, Belvins RL, Frye WW, Peters SE, Christenson DR, Pirece FJ, Vitosh ML: Impact of agricultural management practices on $\mathrm{C}$ sequestration in forest-derived soils of the eastern Corn Belt. Soil and Tillage Research 1998, 47:243-252.

7. West TO, Post WM: Soil organic carbon sequestration rates by tillage and crop rotation: A global data analysis. Soil Sci Soc Am J 2002, 66:1930-1946.

8. Raji BA, Ogunwole JO: Potential of soil carbon sequestration under various land use in the sub-humid and semi-arid savanna of Nigeria, Lessons from long term experiments. Int Journal of Soil Science 2006, 1:33-43.

9. Dumanski J, Desjardins RL, Tarnocai C, Monreal D, Gregorich EG, Kirkwood V, Campbell CA: Possibilities for future carbon sequestration in Canadian agriculture in relation to land use changes. Clim Change 1998, 40:81-103.

10. Gebhart DL, Johnson HB, Mayenx HS, Polley HW: The CRP increases soil organic carbon. J Soil and Water Conserv 1994, 49:488-492.

11. Ramussen PE, Albrecht SL, Smiley RW: Soil $C$ and $N$ changes under tillage and cropping systems in semi-arid Pacific Northwest agriculture. Soil and Tillage Research 1998, 47:205-213.

12. Studdert GA, Echeverría HE: Crop rotations and nitrogen fertilization to manage soil organic carbon dynamics. Soil Sci Soc Am J 2000, 64:1496-1503.

13. Soil Survey Staff: Keys to Soil Taxonomy. United States Department of Agriculture. Natural Resource Conservation Service, Ninth 2003.

14. Campbell CA, Janzen HH, Paustian K, Gregorich EG, Sherrod L, Liang BC, Zentner RP: Carbon Storage in Soils of the North American Great Plains: Effect of Cropping Frequency. Agron J 2005, 97:349-363.

15. Ellert BH, Janzen HH, McConkey BG: Measuring and comparing soil carbon storage.Edited by: Lal R. Assessment methods for soil carbon. Lewis imprint of the CRC Press, Boca Raton, FL; 2001:131-146.

16. Landon JR, Ed: Booker Tropical Soil Manual: a handbook for soil survey and agricultural land evaluation in the tropics and subtropics. John Willey and Sons Inc. New York 1991.

17. Anikwe MAN, Obi ME, Agbim NN: Effect of crop and soil management practices soil compactibility in maize and groundnut plots in a Paleustult in southeastern Nigeria. Plant and Soils 2003, 253:457-465.

18. Krull E, Baldock J, Skjemstad J: Soil texture effects on decomposition and soil carbon storage. NEE Workshop Proceedings, 18-20 April 2001 CRC for Greenhouse Accounting, CSIRO Land and Water Australia.

19. Lal R: Soil carbon dynamic in cropland and rangeland. Environmental Pollution 2002, 116:353-362.

20. Bationo A, Kihara J, Vanlauwe B, Waswa B, Kimetu J: Soil organic carbon dynamics, functions and management in West African agro-ecosystems. Agricultural Systems 2007, 94:13-25. 
21. Cole CV, Flach K, Lee J, Sauerbeck D, Stewart B: Agricultural sources and sinks of carbon. Water, Soil, Air Pollution 1993, 70:111-122.

22. Jastraw JD, Boutton TW, Miller MM: Carbon dynamics of aggregateassociated organic matter estimated by carbon -13 natural abundance. Soil Science Society of America Journal 1996, 60:801-807.

23. Unamma RPA, Odurukwe SO, Okereke HE, Ene LSO, Okoli OO: Farming Systems in Nigeria: Report of the benchmark survey of the eastern agricultural zone of Nigeria. NRCRI Umudike Umuahia Nigeria 1985.

24. Mulla DJ, McBratrey AB: Soil spatial variability.Edited by: Sumner ME. Handbook of Soil Science. CRC Books, New York; 2000:

25. Doran JW, Mielke LN: A rapid, low-cost method for determination of soil bulk density. Soil Sci Soc Am J 1984, 48:717-719.

26. Nelson DW, Sommers LE: Total carbon, organic carbon and organic matter. In Methods of soil analysis Part 3-Chemical methods Soil Sci Soc Am Book Ser 5. Edited by: DL Sparks AL, Page PA, Helmke RH, Loeppert PN, Soltanpour MA, Tabatabai CT, Johnson ME, Sumner. SSSA, Madison, WI; 1996:1961-1010.

27. Bremner JM: Total nitrogen. In Methods of Soil Analysis Part 3-Chemical methods Soil Sci Soc Am Book Ser 5. Edited by: DL Sparks AL, Page PA, Helmke RH, Loeppert PN, Soltanpour MA, Tabatabai CT, Johnson ME, Sumner. SSSA, Madison,Wl; 1996:1085-1122.

28. Gee GW, Orr D: Particle-size analysis. In Methods of soil analysis Part 4Physical methods Soil Sci Soc Am Book Ser 5. Edited by: Dane JH, Topp GC. SSSA, 1994 Madison, Wl; 2002:255-293.

\section{doi:10.1186/1750-0680-5-5}

Cite this article as: Anikwe: Carbon storage in soils of Southeastern Nigeria under different management practices. Carbon Balance and Management 2010 5:5.

\section{Submit your next manuscript to BioMed Central and take full advantage of:}

- Convenient online submission

- Thorough peer review

- No space constraints or color figure charges

- Immediate publication on acceptance

- Inclusion in PubMed, CAS, Scopus and Google Scholar

- Research which is freely available for redistribution

Submit your manuscript at www.biomedcentral.com/submit 